\title{
Læring i netbaseret uddannelse i det danske Forsvar
}

\section{Carla Tønder Jessing}

Videncenterkonsulent, lektor, cand.mag

carla.tønder.jessing@cvustork.dk

\section{Henrik Rander}

Videncenterkonsulent, cand.mag

henrik.rander@cvustork.dk

Carla Tønder Jessing er koordinator for Uddannelses- og Erhvervsvejlederuddannelsen, og driftsgruppemedlem i det nyoprettede Nationale Videncenter for Uddannelses- og Erhvervsvejledning, samt medarbejder på en rckke nationale og internationale udviklings- og undersøgelsesprojekter om voksenuddannelse og voksnes lereprocesser, learning centres, og vejledning. Har bl.a. bidraget til bogen Learning centres, udgivet af DIE, Germany 2006.

Henrik Rander har foretaget udviklingsarbejder og har fungeret som underviser i en rcekke netbaserede efter- og videreuddannelsesforløb. Har blandt andet medvirket i transformation af Voksenunderviserudddannelsen ved DLH til en netbaseret udgave i 1998. Beskceftiger sig i øvigt med en bredde af voksendidaktiske tematikker og har blandt andet medvirket $i$ bogen Voksnes læringsrum, 2005, udgivet af Billesø og Baltzer.

I det følgende vil vi belyse resultaterne fra en undersøgelse, vi har foretaget for det danske Forsvarsakademi, og som vedrører Forsvarets nyere udnyttelse af netbaseret uddannelse med et kollaborativt omdrejningspunkt. I det danske Forsvar eksisterer i relation til efter- og videreuddannelse en længere tradition for fjernundervisning, som man stadig kalder det, og som i nyere tid også foregår i elektronisk form, men ved siden af den ganske traditionelle informationsoverførsel eller one-to-one kommunikation er der de seneste år gennemført uddannelse i fleksibel form, altså i en blanding af tilstedeværelse og netbaseret arbejde, hvor der er tale om en kollaborativ organisering. Det er denne dimension, vi har undersøgt med særligt henblik på deltagernes læreproces, og med henblik på at vurdere den didaktiske konstruktion samt at skitsere didaktiske anbefalinger ${ }^{1}$.

\section{Undersøgelsens fokus}

Fokus for undersøgelsen var afdækning af den elektroniske kommunikation udfra en grundide om, at netop kommunikationen er et bærende grundlag for de læreprocesser, som måtte finde sted. Desuden har vi haft fokus på at undersøge læreprocesserne i forbindelse med denne ofte yderst vanskelige kommunikationsproces. Hvilke læreprocesser kan spores i forbindelse med netperiodernes kommunikation? Hvilken form for kommunikation finder sted - planlæggende, social, parallel, diskuterende? Hvorledes oplever deltagerne selv kommunikationen som

\footnotetext{
${ }^{1}$ Forsvarsakademiet 2005, Læring i netbaseret uddannelse i Forsvaret v/Carla Tønder Jessing \& Henrik Rander
} 
læringsinstrument? Hvilken sammenhæng kan indkredses mellem kommunikationen og den didaktiske planlægning? Hvilken sammenhæng kan spores mellem kommunikationen og deltagernes organisationskultur?

Således stillede indgangsspørgsmålene sig, og de udmøntedes siden i følgende tre forskningsspørgsmål:

- Er der sammenhæng mellem uddannelsens organiseringsform og læring?

- Er der en sammenhæng mellem arbejdsformerne og læring?

- Er der sammenhæng mellem kommunikationen på nettet og læring?

De grundlæggende spørgsmål har altså vedrørt forholdet mellem selve uddannelsens organiseringsform og de læreprocesser, der genereres, mellem måder der arbejdes på gennem uddannelsesforløbet og deltagernes læreproces, samt mellem den faktisk udfoldede kommunikation og læring.

Der ligger heri en interesse for at afklare relationen dels mellem den udmøntede didaktik og det der læres, dels mellem måder der kommunikeres på og de tilknyttede læreprocesser. For så vidt angår den sidste dimension er det jo velkendt, at de mangfoldige forestillinger om denne særlige kommunikationsforms potentialer for at understøtte læring ofte ikke bliver indløst, enten fordi der ikke kommer en egentlig udveksling i gang mellem deltagerne, eller fordi det udvekslede aldrig forholdes til hinanden, aldrig forhandles, men blot tages til venlig efterretning. Rattleff peger f.eks. på kommunikationen som usammenhængende, præget af korte tråde, manglende besvarelser på indlæg samt på en høj grad af parallel, monologisk kommunikation ${ }^{2}$.

Resultaterne fra forsvarsundersøgelsen viser sig at afvige fra de ovennævnte karakteristika. I den kontekst undersøgelsen beskæftiger sig med, foregår der en kommunikation med megen udveksling og med høje besvarelsesprocenter, ligesom også udvekslingernes karakter er kendetegnet ved at være substansfyldt og ganske kompleks. Således er diskussions- og forhandlingsniveauet relativt højt. Det kunne altså se ud, som om vi her opererer inden for en sammenhæng, hvor hensigten om den udfoldede kommunikation indfries, hvor de potentialer, der fremhæves i ganske mange sammenhænge ${ }^{3}$, også folder sig ud. I hvert fald lykkes den kommunikative intention for en umiddelbar betragtning - den pædagogiske ide om, at læreprocessen styrkes gennem den asynkrone interaktion deltagerne imellem, har fået gode ben at gå på.

Interessant er det jo så, hvad der er på færde? Hvordan kan det være, at uddannelsesforløb inden for denne organisation kan betragtes som vellykket? Hvad er det særlige i kontekst og organisation?

\section{Undersøgelsens teoretiske og empiriske ramme}

Undersøgelsen arbejder inden for en konstruktivistisk forståelsesramme, hvor tre forhold indgår:

- Fokus på ideen om læring

- Fokus på CSCL

- Fokus på praktikerens måde at indgå i uddannelse på, med henblik på at udvikle praksis

Ideen om, at hensigten med uddannelse og undervisning er læring, understreges. Det danske Forsvar har historisk været uhyre resultatorienteret, også i et pædagogisk perspektiv, og man har således været meget rettet mod resultatet af den undervisning, der har fundet sted,

\footnotetext{
${ }^{2}$ Rattleff 2001, 2002

${ }^{3}$ se eksempelvis Harasim, Mason, Kaye, Sorensen
} 
fokuseret i begrebet om indlæring ${ }^{4}$. Imidlertid er den moderne bevægelse mod et procesorienteret læringsbegreb ${ }^{5}$, hvor der til tider tales om et paradigmeskift, idet fokus for undervisning kan betragtes som flyttet fra det klassisk stoforienterede, formidlende, til grundlæggende at reflektere ideen om læring, også trængt ind i det danske Forsvar ${ }^{6}$, og det har derfor været relevant at forfølge læringssigtet i undersøgelsen. Derfor betragtes læringsbegrebet i et teoretisk perspektiv, hvor Knud Illeris' læringsforståelse præsenteres ${ }^{7}$. Her er det centralt, at læring må begribes som et forhold, hvor såvel kognitive som emotionelle, eller som det hedder hos ham: psykodynamiske, samt sociale dimensioner indgår og er virksomme. Individet er altså på en gang aktivt med den kognitive konstruktion, med en række psykodynamiske processer, og med en social aktivitet og interaktion i forbindelse med læreprocesserne. En given læreproces må derfor betragtes i dette lys, hvorfor også en given didaktisk organisering må reflektere denne forståelse.

Videre arbejder vi i den teoretiske ramme på baggrund af ideen om kollaborativ læring, således som den er behandlet inden for Computer Supported Collaborative Learning. Kollaborativ læring tager afsæt i en arbejdsform, hvor uddannelsesdeltagerne bearbejder stof inden for en gruppeorganisering, og hvor grupperne stilles over for forskellige opdrag (opgaver, projekter), der altså fungerer som omdrejningspunkt for læreprocessen. En egentlig definition på begrebet kollaborativ læring gives ikke, men undersøgelsen arbejder med en forståelse med disse tre karakteristika:

1) i samarbejdet i en gruppe foregår fælles konstruktion af viden

2) gruppen arbejder frem mod et defineret og fælles anerkendt mål

3) der gælder en gensidig forpligtethed på målet mellem gruppens medlemmer.

Undersøgelsen er centreret om følgende fire forhold i uddannelserne:

1) uddannelsesforløbet er struktureret i en blanding af tilstedeværelse og netbaseret egenaktivitet

2) uddannelsesforløbet er struktureret efter et kollaborativt princip

3) deltagernes netbaserede samarbejde foregår asynkront

4) den netbaserede dialog er skriftlig.

Det betyder, at undersøgelsen dels tager afsæt i disse fire forhold eller karakteristika, dels at den har forsøgt at forfølge betydningen af disse forhold i relation til det læringsmæssige udkomme, og endelig at den fører frem til en vurdering af det didaktiske grundlag.

Endelig indgår som teoretisk forståelse et syn på deltageren som professionel eller som praktiker, der opererer inden for en bestemt erhvervspraksis, som uddannelsesforløbet tænkes at kvalificere yderligere. Det er overhovedet ideen med efter- og videreuddannelse at kvalificere og udvikle den praksis, der i forvejen er etableret, og da de undersøgte forløb netop retter sig mod efter- og videreuddannelsesfeltet, er det oplagt at reflektere denne dimension. Hertil har vi inddraget Peter Jarvis' begreb om praktiker-forskeren ${ }^{8}$. Her er det centralt, at praktikeren netop medbringer eller inddrager sine praksiserfaringer i det uddannelsesforløb, hvor teori tænkes at kunne virke perspektivudvidende og kvalificerende. Jarvis’ pointe er, at det er nødvendigt at reflektere og forholde sig til den eksisterende praksis og mening, således som den stiller sig for deltageren, hvorpå det muliggøres, at deltageren udvikler sin egen

\footnotetext{
${ }^{4}$ se hertil Forsvarskommandoen 1998

${ }^{5}$ se f.eks. i et voksenuddannelsesperspektiv Jarvis 1992, i et social-interaktivt perspektiv Dysthe, i et perspektiv omkring distribueret kognition Engeström samt Hansen m.fl., i et socialt læringsperspektiv Wildesmeersch

${ }^{6}$ Forsvarskommandoen 2003, Rander

${ }^{7}$ Illeris 2003

${ }^{8}$ Jarvis 2002
} 
personlige teori. Personlig teori betyder praktikerens egen fortolkning og omsætning af erfaringer og ny viden - herunder eksplicit teoretisk viden - ind i praksis. Teori om hvorfor, altså teori om hvad der bør ligge til grund for praksis, forestillingen om den gode praksis, tilføres løbende, men den indgår ikke ufiltreret eller koblingsfrit i praksissituationerne. Praktikeren foretager sin egen oversættelse, hvor allerede skabte erfaringer og holdninger er regulerende for indoptagelsen af det ny. Praktikeren forsøger at skabe sin egen personlige forståelse af, hvordan han/hun kan skabe praksis - den personlige teori. Således er den personlige teori en teori om praksis. Der er tale om en praktisk viden, som både omfatter proces og indhold, hvorfor og hvordan.

Pointen i relation til uddannelsesvirksomhed for praktikeren er, at praktikeren bærer praksiserfaring med sig ind i efter- og videreuddannelsen, og gennem tilførelsen af teori, som netop kobles til praksis, kan hun kvalificere sin viden og tilgang til praksis, skabe eller videreudvikle sin personlige teori og herefter returnere til nye praksissituationer og afprøve den udviklede personlige teori.

Undersøgelsen fokuserer på to forskellige efter- og videreuddannelsesforløb for officerer, der løber over henholdsvis 44 og 23 uger. Begge forløb har et pædagogisk genstandsfelt, idet de er rettet mod uddannelsesplanlæggere, undervisere og uddannelsesledere. Undersøgelsens empiriske grundlag udgøres dels af en observationsundersøgelse af den netbaserede kommunikation. Her er 14 grupperum med i alt 823 meddelelser blevet observeret og fortolket. Dels har vi efterfølgende foretaget en række smågruppeinterviews (2-3 deltagere) baseret på det kvalitative forskningsinterview.

For så vidt angår observationerne har vi struktureret dem med udgangspunkt i en kategorisering udviklet af Pernille Rattleff ${ }^{9}$. Her fortolkes meddelelser overordnet ind i de tre kategorier: organisatoriske meddelelser, faglige meddelelser og personlige/sociale meddelelser. Endvidere har Rattleff anvist en høj detaljeringsgrad i sin underopdeling af kategorierne, og dette princip har vi fastholdt, dog således at vi udviklede egne kategorier i forhold til den type af kommunikation og de konkrete udsagn, som rummes i vores undersøgelse (se bilag A\&B).

Alle meddelelser blev fortolket i relation til kategoriseringen og plottet ind i et skema, foretaget så der kunne skelnes mellem udspil i en kommunikation og besvarelser på udspil, samt andre besvarelser. Således blev det også muligt at afdække samtaletrådene og analysere disse for bevægelser, type af indlæg samt flowet i samtalen. Og det var altså muligt at vurdere trådene for balancen mellem organisatoriske, egentligt faglige og personligt/sociale indlæg.

\section{Den observerede kommunikation}

Kommunikationsmønstret viser sig markant anderledes, end det ses i andre undersøgelser. Således er allerede besvarelsesmønstret anderledes med en høj grad af besvarelser på indlæg på konferencerne. Hvor andre undersøgelser udviser besvarelsesprocenter på de respektive udspil på mellem 40 og $50 \%^{10}$, ser vi i denne kontekst besvarelser på udspil på mellem 63 og 100 \%, mens i alt mere end 83 \% af alle indlæg møder en besvarelse.

Hertil kommer, at udveksling med faglig information ligger højere, end det eksempelvis er set i Rattleffs undersøgelse. I sidstnævnte udgør de faglige meddelelser knap $45 \%$ af det samlede flow af meddelelser, mens der i forsvarsundersøgelsen gælder, at faglig information beslaglægger knap 56 \% af al udveksling. Og går vi et skridt videre og ser på hvor i de faglige meddelelser, der udveksles kreative fortolknings- og løsningsbud samt egentlig diskussion og forhandling, samles de i vor undersøgelse i tre underkategorier under de faglige meddelelser. Disse indlæg udgør i de 14 kursusrum (på nær for et enkelt rums vedkommende) mellem 58

\footnotetext{
${ }^{9}$ Rattleff 2001

${ }^{10}$ Rattleff 2001 s.20\&91
} 
og $100 \%$, og ser vi alene på kategorien diskussion af/supplement til andres faglige input finder vi, at gennemsnitligt 40,9 \% af de faglige meddelelser forefindes her. Altså rummer en meget høj andel af de faglige meddelelser en særlig form for substans.

Alt i alt peger materialet på en udnyttelse af konferencerne og af den netbaserede kommunikation, som ser anderledes konsistent ud, end det ses i andre undersøgelser og erfaringsmaterialer. Og her er det tillige interessant, at de meddelelser, der formodes at repræsentere det største læringspotentiale i kraft af den selvstændige, perspektiverende og syntetiserende anvendelse, hvor der tillige åbnes for koblinger til praksis, repræsenterer en meget stor andel af den samlede kommunikation.

\section{Analysen af interviewundersøgelsen}

I gruppeinterviewene var en række tematikker iøjnefaldende: Deltagerne tematiserede opfattelsen af læring, synet på og oplevelsen af den kollaborative dimension, organiseringen af uddannelsen mellem tilstedeværelse og netarbejde, opfattelsen af netkommunikationen, den asynkrone arbejdsform, skriftligheden, samt endelig den organisationskultur, deltagerne eksisterer inden for. Her skal skitseres nogle få centrale resultater.

\section{Læring og det kollaborative princip}

Sammenfattende vil vi pege på, at deltagernes erfaring var, at uddannelsens læreprocesser havde bestået $\mathrm{i}$ en aktiv tilegnelse af stof og temaer, og at denne tilegnelse foregik såvel individuelt som i fællesskab. Den sidste dimension omkring det kollaborative var tilmed et forhold, som deltagerne understregede som helt væsentligt i relation til deres egen læreproces. Nogle talte om 'erkendelsesmæessigt overskridende lcering', og man understregede endvidere, hvorledes uddannelsens relatering til praksis - ikke mindst i det arbejde som foregik netbaseret - havde været betydningsfuld. Man pegede i øvrigt på, hvordan man under og efter studieforløbet var blevet i stand til at handle anderledes i praksis.

I de gennemførte interviews beskriver de interviewede gruppeprocesser og læringsresultater af gruppeorganiseringen med begreber og karakteristika, der er meget overensstemmende med de begreber og karakteristika, som vi finder i undersøgelsens teoriramme om det kollaborative princip. Det drejer sig om synergi, om udveksling, respons og interaktion, om forpligtelse, om samspillet mellem individuel og kollaborativ læring, og om at læringen ikke nødvendigvis fungerer efter hensigten.

Om synergi bruges der følgende betegnelser og beskrivelser:

- synergieffekten af forskellige erfaringer i gruppen

- dybere bearbejdning af stoffet

- dybere erkendelse ved at vedsupplere hinanden

- udveksling

- respons

Om udveksling, respons og interaktion hedder det:

- dialog med andre for at det rykker

- får flere dimensioner med i gruppearbejde, resultatet bliver mere kvalificeret

- larer noget om psykologi ved at vare i gruppe

- leerer noget om mig selv og dét, jeg leverer mundtligt og skriftligt

Om forpligtethed siges der:

- vigtigt med forpligtende opgave

- betydning at vare forpligtet på hinanden 
I de interviewedes udsagn om samspillet mellem individuel og kollaborativ læring stilles der både en modsætning op mellem individuel og kollektiv læring, og der peges på et frugtbart samspil. Modsætningen består i dybde i det individuelle arbejde og overfladiskhed i gruppearbejde, og i at refleksion forudsætter arbejde alene ("i enrum"). Her bringes generelle erfaringer med gruppearbejde ind i overvejelserne, erfaringer som implicerer skepsis i relation til gruppearbejde. I nogle udsagn forklares dette som udtryk for personligt foretrukken læringsstil, i andre at nogle fag(-områder) bedst læres individuelt. Samtidig udtrykkes det af alle, at i relation til pædagogiske/didaktiske fagområder og problematikker er læringen i grupper essentiel:

- i pcedagogiske kurser lerer man noget andet og mere i grupper

- man larer noget om prcesentationsformen ved at vare i gruppe

- uden gruppearbejde havde kurset vœret nul

- gruppearbejdet førte til lcering om fordele og ulemper ved fjernundervisning

Samlet kunne dette tolkes som deltagernes krav til formål med og kvalitet i den kollaborative organisering.

Om at læringen ikke nødvendigvis fungerer efter hensigten: Kravene til formål og kvalitet kommer desuden indirekte til udtryk i de interviewedes beskrivelser af reaktionen på uklare eller åbne opdrag, eller opgaver de ikke kunne se mening med:

- uklart opdrag førte til frustration i gruppen, der derefter selv konstruerede en opgave

- åbent opdrag gav et "kulturchok" i gruppen

- (oplevet) meningsløs opgave medførte forvirring og frustration

Opdragsproblematikken her er et eksempel på influering på de kollaborative processer, som er modsætningsfuld, idet den i nogle tilfælde førte til egenorganisering af en meningsfuld aktivitet eller til kollektiv læringsrefleksion, og i andre tilfælde førte til initiativmangel, ufrugtbar frustration, eller at deltagere meldte sig ud.

I den teoretiske ramme er der peget på ideen om fælles konstruktion af viden, om betydningen af det definerede og fælles anerkendte mål samt om den gensidige forpligtelse på hinanden. Vi ser her, hvordan interviewene peger i samme retning. At der foregår fælles videnskonstruktion på centrale pædagogiske felter, at der foregår en diskussion af definitionen af de fælles mål, som i sig selv implicerer læring, og at der er tale om gensidig forpligtethed på disse (forhandlede) mål.

\section{Organiseringen som veksling mellem tilstedeværelse og netarbejde}

De interviewede betegner kombinationen af og vekslingen mellem tilstedeværelsesperioder og perioder med netbaseret arbejde som både god og nødvendig, af én interviewgruppe betegnes den som optimal. Ingen ville have foretrukket et rent netbaseret forløb. En enkelt respondent ville have foretrukket et rent tilstedeværelsesforløb (for at undgå opgavepresset på arbejdspladsen i netperioderne), men finder vekslingen både realistisk og geografisk hensigtsmæssig.

I beskrivelserne af de to typer organisering indgår der både karakteristikker af, hvad de hver især kan give, og af hvordan de spiller sammen.

Om det særlige ved tilstedeværelsesmodulerne siges det:

- nødvendige for at lare hinanden at kende

- møder de andres ansigt, mimik, betoninger, holdninger, fortcllinger, føler sym- og antipati 
- få sat tingene på plads, få indspark fra undervisere

- få bekrceftelse af, at arbejdet i netperioderne var godt

- her kunne man få accept fra andre grupper, kolleger, medkursister

- de giver mulighed for "store" diskussioner

Og om det særlige i de netbaserede perioder - hvor der både peges på positive sider og faldgruber:

- interaktivitet på nettet er guld verd, giver et meget bedre forløb

- der er megen støj i det netbaserede arbejde, og ind imellem gyldne øjeblikke, der scetter noget i spil, der skal gøres en indsats

- eleverne bliver ens i fjernundervisning

Der tales i de to karakteriseringer om dét, der i undersøgelsens teoretiske ramme kaldes multisemiotisk og mono-semiotisk: At i tilstedeværelsesdelene er alle sanser involveret, og en lang række kommunikative tegn kan udnyttes i face-to-face-interaktionen, og at netkommunikationen er mono-semiotisk, den baserer sig udelukkende på skrevne tegn ("eleverne bliver ens"). I den netbaserede interaktion savnes det kendskab, man får til de andre deltagere gennem tilstedeværelsen. Derfor peger alle på tilstedeværelsen som helt nødvendig for kommunikationen i netperioderne.

Om dette samspil siges der:

- tilstedevcerelsesseminarerne er nødvendige for udbyttet af netarbejdet

- det er vigtigt at begynde med tilstedevcerelse

- det er afgørende for kommunikationen på nettet

- kendskabet til de andre muliggør nuancer i tolkningen af kommunikationen på nettet

Man kan altså sige, at forskelligheden og samspillet mellem de to organisationsformer af de interviewede reflekteres eksplicit i relation til læring.

\section{Netkommunikation og skriftlighed}

Deltagerne var mere utydelige på, hvilken betydning selve netkommunikationen havde haft i forhold til deres læreproces. Man pegede på, at kommunikationsfrekvensen vokser, 'når diskussionen er interessant', ligesom man fandt, at kvaliteten af interaktionen voksede i sådanne situationer, men de interviewede så ikke mere systematisk på kommunikationsformen, ligesom deres billede af fordelingen mellem organisatoriske, faglige, personlige/sociale meddelelser ikke stemte overens med det faktiske billede.

Derimod herskede der stor bevidsthed omkring kommunikationens skriftlighed. Over hele linien peges der på, at det der i udgangspunktet synes som en pragmatisk foranstaltning - at udveksle meddelelser - får en ganske anden læringsmæssig konsekvens. Der foregår en understøttelse af læreprocessen i kraft af det skriftlige formuleringsarbejde, mener deltagerne.

Det udtrykkes af alle interviewede, at skriftligheden - trods utryghed og uvanthed i begyndelsen - er en stor styrke ved de netbaserede dele af forløbene, og det forbindes med læreprocesser. Det udtrykkes bl.a. således: At "tingene sidder bedre fast", man får "det bearbejdet på en anden måde" det "bliver til kategorier, jeg kan anvende", man er "nødt til at komme dybere ned i materien", "man tcenker mere over, hvad man skriver, og hvordan man skriver", og at det fører til "lcering, der har lagt sig".

Ved at sammenholde udsagnene om skriftligheden med den anvendte teoriramme, er der stor overensstemmelse i relation til, hvad skriftligheden gør for refleksionen og læreprocessen: At det udvekslede altid kan fremdrages, undersøges og belyses på ny, at den kan understøtte 
udviklingen af metakognitive færdigheder og metakommunikative færdigheder, at den kan virke som redskab for erkendelsesprocesser og individuel og kollaborativ læring.

\section{Kulturen}

Endelig pegede deltagerne selv på, hvordan deres 'opdragelse' i det militære system har udrustet dem med en disciplin og ikke mindst med en fællesskabs- og ansvarsfølelse, som er befordrende i forhold til det kollaborative uddannelseskoncept. Man forventer ansvarlighed fra sine omgivelser, ligesom man selv udviser den. Man betragter det som en selvfølge, men også som et dannelseselement, der er tale om en grundlæggende værdi, man opererer udfra. Endelig er man uddannet til at strukturere og organisere komplekse opdrag, hvilket respondenterne også oplevede kom dem til gode i netsituationen, hvor det kan være vanskeligt at danne sig et overblik.

Deltagerne fremhævede Forsvarets historiske læringsopfattelse som værende i modsætning til netuddannelsens konstruktivistiske læringsprincip. Dette at give sig i kast med tidskrævende processer, der tillige kan være svært målbare, kan stå i et modsætningsforhold til Forsvarets klassiske kultur, men omvendt pegede man også på, at netop denne klassiske opfattelse er under opbrud, og at det netbaserede forløb kan virke understøttende på et nyt pædagogisk rationale.

Vi ser altså, hvordan organisationskulturen rummer gode forudsætninger for at udnytte CSCL som læringsplatform, men hertil kommer, at den didaktik, som er praktiseret på uddannelsesforløbene, må betragtes som medvirkende til at give oplevelse af et stort læringsudbytte.

\section{Didaktiske anbefalinger}

Her kan der for det første peges på organiseringen i en blanding mellem tilstedeværelse og netarbejde. Deltagerne lagde stor vægt på betydningen af at kunne mødes som en understøttende aktivitet i forhold til at formidle den produktive netkommunikation ${ }^{11}$. Vi har i undersøgelsen ikke haft lejlighed til at sammenligne med netbaserede forløb uden fremmøde og kan derfor ikke sige noget om, hvordan et sådant kunne udfolde sig, men det synes oplagt at inddrage tilstedeværelse i det omfang, det er logistisk muligt, da det må opfattes som fremmende for de medvirkendes læreproces.

I forhold til den vellykkede kollaboration er det tydeligt, at der må arbejdes med tydelige og præcise opdrag. I forløbene er der stillet opgaver af meget forskellig karakter, fra den løst diskuterende over den målsatte til projektopgaven, hvor deltagerne stilles over for selv at udvikle en problemformulering. Vi finder, at hvis dialogen skal iværksættes meningsfyldt og motiverende og ligeledes lægge op til en fælles, kvalificeret behandling af stoffet, er klarhed og tydelighed nødvendig. Altså præciseringen af målet, og i forlængelse heraf en præcisering af rammerne for afviklingen. Gruppen skal altså indledningsvis være i stand til at dedikere sig på et tydeligt og fælles mål, ligesom rammer for eventuel afrapportering må være tydelige.

Endvidere er det naturligvis centralt, at opgaven giver mening. Man kunne i denne sammenhæng tale om et relevanskriterium. Mening vil i denne sammenhæng sige, at der skal kunne kobles til deltagernes praksis, jf. ideen om praktikerens mulighed for at udvikle personlig teori, som tager afsæt i praksis og medvirker til en videreudvikling af samme.

En sidste anbefaling, som undersøgelsen leverer, vedrører i højere grad at arbejde metakommunikativt. At der iscenesættes refleksioner over, hvorledes kommunikationen forløb, hvad den drejer sig om, og ikke mindst hvordan den kan kvalificeres yderligere. Det var overraskende for os, hvorledes deltagerne i det store og hele ikke havde fornemmelse af,

\footnotetext{
${ }^{11}$ om betydning af f2f se f.eks. Hansen m.fl., Bygholm \& Dirckinck-Holmfeld, Cheesman \& Heilesen
} 
hvordan kommunikationen havde udfoldet sig i relation til de tre hovedkategorier. Vi forestiller os, at en fokusering på dette felt, hvor deltagerne refleksivt betragter deres egen dialog, kan medvirke til at skærpe den kvalificerede dialog og dermed det samlede udkomme.

Samlet peger vores undersøgelse altså på opmærksomhed på nogle specifikke didaktiske felter:

- Det kollaborative princip som et nyttigt grundlag

- Organisering vekslende mellem tilstedeværelse og netarbejde tilstedeværelsesseminarer som frugtbare og væsentlige

- Etablering af tydelige mål og rammer for opdragene i netarbejdsperioderne

- Fokus på og refleksion over kommunikationen

Det har været interessant at møde netbaserede uddannelsesforløb, som gør den typiske erfaring omkring den manglende kommunikation og den manglende substans i udvekslingerne til skamme. Det har været dybt interessant for os, hvordan det mon kan være? Som et i sig selv interessant fænomen, men i nok så høj grad, fordi det skærpede vores nysgerrighed på, hvilke elementer af mere almen karakter, der kan uddrages af denne erfaring.

Det står os klart, at den organisatoriske kontekst er vældig betydningsfuld for den form for udfoldethed, vi møder her. Ikke sådan at forstå, at et organisationsforankret uddannelsesforløb i sig selv kan antages at blive vellykket, men den organisatoriske kontekst kan være fremmende eller begrænsende for ønsket og ideen om en frugtbar deltageraktivitet. Her bør en særlig opmærksomhed gøre sig gældende, når man iværksætter netbaseret uddannelse.

Og hertil kommer de mere alment didaktiske principper, som vi finder er betydningsfulde, og som meget enkelt kan tænkes ind i andre sammenhænge: Forsøg på at understøtte den skriftlige dialog gennem en særlig måde at tildele opdrag på. Forsøgene på således at skabe relevans, meningsfuldhed og udfordring. 


\section{Bilag A}

\section{Organisatoriske meddelelser}

Kategorien organisatorisk angiver, at en meddelelse har praktisk-organisatorisk information. Operationel definition: Hvis en meddelelses primære indhold rummer et eller flere af følgende elementer, kategoriseres meddelelsen under kategorien organisatorisk.

1) Tidspunkter (dage, datoer, klokkeslæt for konferencer/møder/chats) \& steder (mødes på chat eller fysisk)

2) Adresser (e-mails, webadresser, fysiske adresser, samt lån/kopiering af materiale, telefonnumre)

3) Organisering af møde (opfordring til møde/organisering af chat/etablering af mødedagsorden)

4) Referat af chats

5) Aftaler/ansvarspåtagelse (fra enkeltpersoner, f.eks. meldinger om egen proces) \& generel organisering (statusmeldinger på den fælles opgave/organisering af vejlederbrug/afbud/aflysning)

6) Tilkendegivelser (om at indlæg er læst/andre tilkendegivelser/anerkendelse)

7) Whereabouts-meldinger, herunder f.eks. arbejdstider

8) Drøftelse af ordstyrer-, moderatorrollen/organisering af ordstyrer, moderator

9) Hvem er i gruppe med hvem? Hvem løser hvilke opgaver? Organisering af arbejdsfordeling \& tidsplaner for arbejdet i arbejdsgruppen

10) Organisering af konference(r)/mapper/overskrifter på mapper/henvisning til anden mappe

11) Formalia i forbindelse med opgaveafleveringer (antal sider, datoer)

12) Teknikspørgsmål/-konstateringer/-bemærkninger/-problemer/-prøver

13) Metakommunikative spørgsmål - f.eks. hvad svares der på her?

\section{Faglige meddelelser}

Kategorien faglig angiver, at en meddelelse har faglig information.

Operationel definition: Hvis en meddelelses primære indhold rummer et eller flere af følgende elementer, kategoriseres meddelelsen på kategorien faglig.

1) Faglig reference/gengivelse (f.eks. tekst/bogtitel/kilde/webadresse)

2) Refererende opgavetekst

3) Referat af faglig tekst

4) Personlige synspunkter (meninger, holdninger, vurderinger) i forhold til stof/opgave/fag eller erfaringstilknytning/fortolkning

5) Oplæg/løsning/diskussion/dialog vedr. opgave eller fremstilling i f.m. bedømmelse

6) Kommentar til andres faglige kommunikation (f.eks. tak, fint, godt, gode pointer, ikke-begrundet eller umiddelbar tilkendegivelse af enighed)

7) Diskussion af/supplement til andres faglige input

8) Organisering af læsning/vægtning/orientering

9) Organisering og diskussion af studiegruppens opgavefremlæggelse/fremstilling på seminar

10) Spørgsmål til vejleder/udveksling mellem gruppemedlemmer vedr. vejlederkommentarer

11) Meddelelser fra vejleder (evt. via moderator)

\section{Personlige/sociale meddelelser}

Kategorien personlig/social angiver, at en meddelelse rummer personlig/social information. Operationel definition: Hvis en meddelelse primært indeholder et eller flere af følgende elementer, kategoriseres meddelelsen på kategorien personlig/social.

1) Småkommentarer/smileys/(selv)ironiske/vittige kommentarer

2) Hilsener: God ferie, glæder mig til vi ses, til lykke, tak for hjælpen samt tilbud om hjælp

3) Beskeder af forklarende eller undskyldende karakter i f.m. ikke at have overholdt aftaler/udført opgaver 


\section{Bilag B}

Organisatoriske
\begin{tabular}{|l|l|l|l|l|l|}
\hline Udspil & Svar & Udspil & Svar & Udspil & Svar \\
\hline $\mathrm{X}$ & & & & & \\
\hline & $\mathrm{X}$ & & & & \\
\hline $\mathrm{X}$ & & & & & \\
\hline & $\mathrm{X}$ & & & & \\
\hline & $\mathrm{X}$ & & & & \\
\hline & $\mathrm{X}$ & & & & \\
\hline & & $\mathrm{X}$ & & & \\
\hline & & & $\mathrm{X}$ & & \\
\hline & & $\mathrm{X}$ & & & \\
\hline & & $\mathrm{X}$ & & & \\
\hline & & & $\mathrm{X}$ & & \\
\hline & & & & & $\mathrm{X}$ \\
\hline & & & & & $\mathrm{X}$ \\
\hline & & & $\mathrm{X}$ & & \\
\hline & & & $\mathrm{X}$ & & \\
\hline
\end{tabular}




\section{Litteratur}

Bygholm, Ann \& Dirckinck-Holmfeld 1997: Pædagogik i det virtuelle læringsmiljø - metodiske overvejelser $i$ Danielsen (red.), Lcering og multimedier, Aalborg Universitetsforlag

Cheesman, Robin \& Heilesen, Simon B. 1999: Supporting Problem-based Learning in Groups in a Net Environment I Proceedings of Computer Support for Collaborative Learning, Stanford University

Dysthe, Olga 1997: Det flerstemmige klasserum, Klim

Engeström, Yrjö 2000: Udviklingsarbejde som uddannelsesforskning i Illeris(red.), Tekster om lering, Roskilde Universitetsforlag

Forsvarskommandoen 1998: Ledelse og uddannelse

Forsvarskommandoen 2003: Pcedagogiske Principper for Forsvaret

Hansen, Dirckinck-Holmfeld, Lewis, Rugelj 1999: Using Telematics for Collaborative Knowledge Construction I Dillenbourg (red.), Collaborative Learning - Cognitive and Computional Approaches, Pergamon

Harasim, Linda 1990: Online Education: An Environment for Collaboration and Intellectual Amplification I Harasim (red.), Online Education - Perspectives on a New Environment, Praeger

Illeris, Knud 2003: Voksenuddannelse og voksenlcering, Roskilde Univeristetsforlag/Learning Lab Denmark

Jarvis, Peter 1992: Paradoxes of Learning, Jossey-Bass Publishers

Jarvis, Peter 2002: Praktiker-forskeren, Alinea

Kaye, Anthony 1992: Learning together Apart I Kaye (red.), Collaborative Learning through Computer Conferencing, The Najaden Papers, Springer-Verlag

Mason, Robin 1994: Using Communications in Open and Flexible Learning, Kogan Page

Rander, Henrik 2004: De pæedagogiske principper og virtuel lcering, Paideia Forsvarsakademiet

Rattlef, Pernille 2001: Studiegruppers faglige diskussioner i computerkonferencer i et fjernstudium, Ph.d.afhandling, Danmarks Pædagogiske Universitet

Rattlef, Pernille 2002: Fleksible, netbaserede fjernstudier i Uddannelse, læering og IT, Uddannelsesstyrelsen

Sorensen, Elsebeth Korsgaard 1997: På vej mod et virtuelt læringsparadigme $i$ Jacobsen (red.), Refleksive lererpocesser, Politisk Revy

Wildesmeersch, Danny 1998: Social learning as a social change - social change as social learning I Illeris (red.), Adult Education in a Transforming Society, Roskilde University Press 